\section{The Teacher as Storyteller and Poet}

\section{Bill Moore and Raymond Chodzinski}

$\mathrm{R}$ ecently I spoke with long time acquaintance and inspiration, Mr. Bill Moore. Bill is a well known author, dramatist, poet, storyteller, master teacher and lover of books. Together we discussed his love of poetry and story within the context of his 45 year career as an educator. What follows is a portion of our conversation, written as the story unfolded.

\section{Chodzinski:}

Bill, it is my belief and I know you agree, that the use of poetry and story in classrooms is imperative. And that all teachers can and should be good storytellers. And that they should try to integrate stories and poetry throughout the full spectrum of classroom curriculum. Simply put: Why?

\section{Moore:}

Storytelling helps to pique curiosity, improve motivation and promotes good language development skills such as listening, speaking, reading and writing. It also helps to explain difficult life skill concepts and can be helpful as a tool in motivating students to see things from a different perspective. Stories are not reserved for the compulsory literature or language class. These can be boring and dull and far too restrictive. Stories and poems need to be seen within a context that stimulates imagination and curiosity. Science and mathematics are good new starting points.

\section{Chodzinski:}

I teach teacher candidates that the key to a good story experience is in the way it is told or retold. What are your thoughts about this?

\section{Moore:}

Exactly! I believe that a teacher who has developed a love for vocabulary can inspire children to be lovers of poetry and story-tales. Even if telling is not your thing then reading is the next best thing. I recall in my early years (now sometime back I might add) how lucky I was in elementary school to have teachers read and tell stories and poetry. My love for poetry came from those episodes and I still recall with fondness the memories and adventures as my mind conjured up the colour and adventure inspired by those words. People and books hooked me on poetry and story telling and I have devoted a life time to helping children realize what I was fortunate to have experienced. I teach teachers how to help children experience the love of believing in story and poetry.

\section{Chodzinski:}

How might a teacher who is interested in introducing story and poetry to a classroom of eager souls begin?

\section{Moore:}

The first lesson I learned many years ago and have taught is that you must believe in the magic of vocabulary. You must maintain a voracious appetite and clutch at every new idea that comes along to see how it might work and improve knowledge in the and out of the classroom. Most important teachers must read and try to find ways to include story and poetry in all aspects of a curriculum be it history, mathematics, science, or language arts.

\section{Chodzinski:}

Sadly it seems that so much time is spent on managing an increasingly complex and overburdening curriculum that reading out-loud to children is a forgotten time. What are your thoughts as to how teachers might include storytelling and poetry in classroom activities?

\section{Moore:}

First and foremost they must make a concerted effort to include stories and poetry on a regular basis. They should choose stories and poems that have good general appeal. They may be funny or chilling. They be mysterious and full of intriguing images of far away places and great deeds. Don't overlook traditional nursery rhymes, fables, myths and folk tales. Although they may be "standards" they have appeal. Include stories that reflect the multicultural flavour of your school community, emerging new storytellers, first nation and aboriginal tales. Look for anthologies that provide a variety of stories and poems from which to select. Most important is to choose a story or poem that is easy for you to tell or recite as it may be. Practice and perform it for a variety of audiences. Try out different variations and acquire a fit with self and with the lesson that is being taught.

\section{Chodzinski:}

I believe that all children love to listen to a good reader or teller who obviously knows the story or poem and is able to bring life to the words. In your opinion, how does a teacher bring this skill to the classroom experience?

\section{Moore:}

Well, that's simple enough! Aside from including practiced, teacher 
led stories and poems, teachers and parents for that matter, must encourage children to create and tell their own stories and poems. Include opportunities for dramatization, vocabulary exploration and creative discussion. Children need to be a part of the show and must be encouraged to know and believe that their contribution is important and worthwhile. For instance a poem I wrote always produces a variety of perspectives.

Would you like to see my secret hiding place?

It's a mystery cave in outer space. Between our house and the house next door:

It's a place no ones ever seen before!

Jane and I play there all concealed; And we keep bad guys out with our own force field;

(That's a bunch of stones and an old deck chair)

There's nowhere like it anymore.

Ask: do you have a secret hiding place? Tell a story or a poem about your secret place. With whom do you share your secret places? Create a play a song a poem or even a movie. Whatever works to encourage children to tell the story!

I love to recite this short but compelling poem.

Most of the time
I'm
Brave.
Very grown up;
But when lightning flashes,
And thunder crashes,
Even though I'm sort of prepared-
I'm scared

This short but effective telling ignites children to share stories about when they are scared. They are easily encouraged to create stories about scary situations and develop vocabulary and drama that portrays the experiences they describe.

\section{Chodzinski:}

It is my experience that the telling or reading of stories and poems is en- hanced when the teacher takes time to expose students to an exploration of sounds through rhythmic beats, chants and the spectrum of noises and voices that match the words heard and told. I like to use drums, rattles, and bells. Do you agree?

\section{Moore:}

Definitely, children and adolescents should be encouraged to feel the magic of the "dance" so to speak and to experience vocabulary through expressive arts such as drama, painting and music.

\section{Chodzinski:}

Some of our readers might think your advice applies only to younger children. What are your thoughts?

\section{Moore:}

Adolescents particularly use stories and poetry to express their feelings, their aspirations and their life moments. As I have said previously, as adolescents mature they bring to the learning table curiosity about life skills, justice, history, culture, self identity and political realities. These topics are fertile ground for the teacher and would be storyteller and poet.

\section{Chodzinski:}

You have often said that storytelling story reading and poetry are essential learning modalities that will enhance a child's classroom experience and bring a sense of joy to a child and adolescents life. How so?

\section{Moore:}

Not only will these types of activities bring joy they will, I believe, ensure long lived memories much like the ones I enjoy privately today.

\section{Chodzinski:}

I am fondly reminded of a line by $E u$ gene Bertin who said "It is not what is poured into the student, but what is planted that counts." What closing message do you have for the teacher who aspires to be a poet and storyteller?

\section{Moore:}

I recall lines that David Booth and myself as authors used to open and close our book Poems Please: Sharing Poetry with Children: The Magic of Poetry (I include storytelling and story reading) lies in its mystery and memories, every word replete with the voices of the children who passed through our lives... were gifts for us. Your life as a teacher is an unfolding poem/story. Your experiences illuminate your present classroom moments. The children discover your parents, your teachers, your personal poetry and story past, revealed in your choice of words, your manner of reading and telling them and your attitude towards them, your eyes as you share them. You are the poem, the story, the telling.

\section{References}

Moore, Bill and Patrick Lasmir. 1990. Under the Hose. Hamilton, ON: Tree House Press, Inc.

Booth, David and Bill Moore. 1988. Poems Please: Sharing Poetry with Children. Markham, ON: Pembrooke Publishers Ltd.

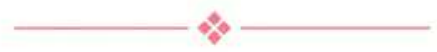

Bill Moore is a consummate educator. His forty five years of teaching children and teachers about language and poetry and story is hailed as a milestone in Ontario Education. He has published numerous plays, poems and books in Canada, United States and the United Kingdom. His love of literature exudes through his poetic style of speaking

and teaching. 